\title{
Andrzej Wirth \\ Lehrstücke jako performance \\ Moje doświadczenia ze „sztukami dydaktycznymi” \\ Bertolta Brechta
}

Moje obserwacje odnoszące się do Lehrstücke (zwanych w Polsce także „sztukami nauczającymi” [Sugiera]) wynikają z osobistego, 25-letniego doświadczenia w teoretycznej i praktycznej pracy zmierzającej do ich performatywnego i medialnego zastosowania. Eksperymenty w tym kierunku prowadziłem na uniwersytetach w czterech różnych krajach, na trzech kontynentach. Brali w nich udział zarówno zaawansowani, jak i początkujący studenci, uczestniczący w seminariach poświęconych analizie wybranych tekstów. Uniwersytety amerykańskie zapewniały doskonałe warunki: dostęp do bibliotek, sal prób i techniki teatralno-medialnej.

Nie towarzyszył nam jednak nigdy zamiar stworzenia czegoś, co stałoby się artystycznym „sukcesem” w potocznym rozumieniu tego słowa. Praca nasza zawsze odbywała się w atmosferze eksperymentu, jako próba poszukiwania nowych rozwiązań. Uczestniczyli w niej studenci różnych kierunków - dramatu, sztuk pięknych, różnych filologii, a także nauk ścisłych - studenci teatrologii i germanistyki nigdy nie stanowili większości.

Prace nad sztukami nauczającymi Brechta rozumiałem jako proces. Na każdym jego etapie poszukiwałem innych rozwiązań napotykanych problemów, uwzględniając równocześnie doświadczenia wcześniejsze (przy czym punktem wyjścia zawsze były tłumaczone teksty Decyzji [Die Massnahme] i Fatzera [Fatzer Material]).

W roku 1978 zadałem studentom St. Antony's College w Oksfordzie pytanie, czy możliwe jest stworzenie spójnego, całościowego performance bez prób, opierając się jedynie na generowanych komputerowo - a więc medialnie - rozrzuconych fragmentach tekstu.

Praca nad tekstem zajęła jeden semestr akademicki. Analizowany materiał literacki pochodził z Fatzera (Fatzer Material) - nieukończonego obszernego fragmentu znamionującego fazę przejścia od dramatu do 
sztuki nauczającej - który co prawda nie jest już dramatem, ale nie jest także jeszcze konsekwentną Lehrstück. Projekt ten, pisany około roku 1931, pod koniec swego życia uważał Brecht za najbardziej zaawansowany formalnie koncept teatru przyszłości.

Spadkobiercy autora nie udostępniali Fatzera niemieckim germanistom. Mnie udało się wszakże uzyskać zgodę Stefana Brechta na zbadanie mikrofilmu typoskryptu przechowywanego w Bibliotece Houghtona na Harvardzie.

Sporządziłem kopię typoskryptu i wspólnie z amerykańskimi germanistami A. Leslie Willsonem i Davidem J. Wardem przetłumaczyliśmy tekst na angielski. Decydując się na wystawienie Fatzera w studiu telewizyjnym na Uniwersytecie Stanforda ${ }^{1}$, zaaranżowałem performance na podstawie jego fragmentów wybranych na semestralnym seminarium.

Zaproszeni goście, około 24 osób, zostali wezwani do interakcji z performerami zgodnie $\mathrm{z}$ zasadami partytury. Recytowali zatem wraz $\mathrm{z}$ innymi wykonawcami fragmenty wypowiedzi chóru, a także zachęcani byli do podejmowania improwizowanych ad-lib ingerencji w krótkich scenkach dramatycznych.

Performerzy i goście zgromadzili się przy pulpitach na nuty, na których umieszczono scenopisy. Uformowane $\mathrm{w}$ ten sposób koło stanowiło naturalną przestrzeń gry, w której aktorzy i goście połączeni zostali w performatywnym akcie wykonawczym. Koncepcja użycia koła jako najprostszej definicji przestrzeni dla akcji zastosowana została także dwa lata później, w eksperymencie oksfordzkim.

Praca w Oksfordzie była odpowiedzią na pytanie, które zadano mi rok wcześniej: czy można stworzyć performance bez prób i bez publiczności jako biernych świadków, performance, będące sui generis samogrą. Zafascynowany poetycką siłą tekstu Brechta, chciałem zbadać, czy wytrzyma on medialną dekonstrukcję. Pomocny okazał się komputer, swoiste novum tamtego czasu. Ówczesny komputer używał perforowanych kart, drukując na nich tekst rozbity na fragmenty, tnąc go zgodnie ze składnią (syntaksa).

Karty drukowane były w dwóch wersjach: jeden ich zbiór zawierał słowa lub części zdań, inny - instrukcje prostych ruchów (np. zrób trzy kroki w kierunku środka koła i jeden w prawo). Pomysł polegał na tym, by niczego nie wyjaśniać, by wszystko tłumaczyło się samo.

${ }^{1}$ Zob. A. Wirth, Brecht's Fatzer, Experiments in Discourse Making, „Theatre Drama Review" 22, 4 (TDR, T80), s. 55-66. 
Lokalna gazeta opublikowała ogłoszenie, zapraszające chętnych do udziału w parateatralnym eksperymencie, nazwanym - dość tajemniczo - FATZER. W wyznaczonym czasie w holu uczelni pojawiło się kilkanaście zainteresowanych osób. Nie była to przypadkowa ani łatwa publiczność, stanowili ją bowiem przedstawiciele sceptycznej społeczności akademickiej, przekonani o swoim wysokim statusie - zarówno studenci, jak i profesorowie. Powitali ich młodzi gospodarze, moi studenci, rozdając białe podkoszulki, na których widniał napis FATZER i kolejne numery od 1 do 12. Gości wezwano, aby ustawili się na narysowanym kredą na podłodze okręgu w kolejności podyktowanej numerami na koszulkach.

Asystujący mi studenci połączyli dwa rodzaje wygenerowanych przez komputer kart, po czym rozdali je wśród uczestników eksperymentu, zgodnie z przyznanymi im numerami. Ja sam stanąłem na uboczu z dużym gongiem, nie jako reżyser, ale jako specyficzny mistrz ceremonii albo raczej aranżer gry. Reżysera - w tradycyjnym rozumieniu tego słowa - nie było.

\section{4}

Kiedy uderzyłem w gong, potoczyła się samogra zainicjowana przez FATZERA numer 1. Poruszył się on trzy kroki do środka koła i krok w prawo i wypowiedział przypadające mu słowa. Inni uczestnicy zdarzenia, zgodnie z kolejnością przypisanych im numerów, przemierzali podobną drogę i wypowiadali wylosowane kwestie.

Złożona gra dźwięku i niemal choreograficznego, ustrukturowanego ruchu, rozwijała się przed naszymi oczyma, a tekst, który znaliśmy na pamięć, przybierał nieprzewidywalną i tajemniczą, niemal mistyczną, formę.

Eksperyment oksfordzki potwierdził niezwykle sugestywną siłę języka Brechta, jako materiału dla performance. Pomimo arbitralności i przypadkowości dekonstrukcji dokonanej na tekście utworu, nie spodziewający się niczego uczestnicy eksperymentu, którzy w rzeczywistości stali się mimowolnymi performerami, byli w stanie opisać ideę przewodnią medialnie zdekonstruowanego tekstu. „To coś o anarchiście, który buntuje się przeciwko autorytarnej grupie" - zdania takie padały jako swoiste odkrycia $\mathrm{w}$ następnej części eksperymentu, kiedy (pomimo wściekłych ataków niektórych jego uczestników) podjęto dyskusję. 
Dla aranżerów owej medialnie generowanej samogry szczególnie fascynująca okazała się jej performatywna złożoność. Inaczej zareagowali zaproszeni goście tego eksperymentu. Uważali oni, że stali się ofiarami manipulacji wypowiadającymi mimowolnie słowa, które nie należały do nich. Było $\mathrm{w}$ tym sporo racji. Musieli jednak ponieść koszty wejścia w autorytarny dyskurs, który z definicji jest samowystarczalny, suwerenny i nieobliczalny.

Performance ma moc neutralizowania ideologii. Taka była również konkluzja z mojego eksperymentu nowojorskiego z roku 1973, którego partyturą była Decyzja Brechta (The Measures Taken, Die Massnahme).

\section{6}

Praca w studiu choreograficznym prowadziła mnie w kierunku tańczonego widowiska o precyzyjnej, formalnej choreografii. Powstało taneczne oratorium $-\mathrm{z}$ ustalonym schematem ruchu i tekstem wykonywanym jako dźwiękowy poemat - stając się $\mathrm{w}$ rezultacie rodzajem praktycznego poszukiwania komunikacji wewnętrznej w grupie. Nazywam ją „intymną (intrinsic) komunikacją”).

\section{7}

Byłem zafascynowany siłą performance jako narzędzia do neutralizowania ideologii. Niemcy nazwaliby to zjawisko AUFHEBUNG DER IDEOLOGIE DURCH PERFORMANCE (zawieszenie wymowy ideologicznej poprzez performance). Takie użycie performance wobec sztuki uważanej przez wielu za gloryfikację stalinowskiego terroru i będącej zarazem literackim arcydziełem stało się ideą przewodnią mojej pracy nad sztukami nauczającymi Brechta, koncentrującej się głównie na projekcie Fatzera.

W Nowym Jorku posłużyłem się studentami tańca. Mimo że nie jestem choreografem, ufałem możliwościom przekraczania tego ograniczenia poprzez formalny pomysł na performance.

Dwadzieścia lat później, w roku 1994, na zaproszenie Centre for Performance Studies w Sydney University zaaranżowałem z tamtejszymi studentami kolejne performance oparte na materiale Fatzera. Zaprosiłem do współpracy choreografkę Emmę Lew Thomas z UCLA. Ta była studentka Mary Wigman, odtwarzająca jej choreografie w USA, zyskała międzynarodową sławę przez rekonstrukcje włoskich tańców renesansowych na podstawie literackich opisów z epoki.

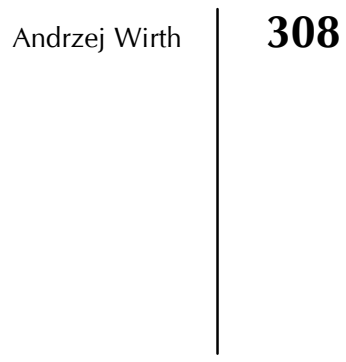


Współpracę z Emmą Lew Thomas kontynuowałem na międzynarodowych warsztatach, które odbyły się we włoskiej Volterze i w Oksfordzie. W Sydney zaaranżowaliśmy performance na podstawie materiału Fatzera. Badaliśmy możliwości ruchu choreograficznego w performance granym bez widzów, opartym na wewnętrznej komunikacji w grupie. Założyliśmy, że ruch poprzedza język. Wyniki tego warsztatu utrwalone zostały na taśmie video i zaprezentowane na międzynarodowej konferencji germanistycznej.

Eksperyment ten uznać można za dowód, że nawet w obszarze odległym od europejskiej tradycji ideologicznych dyskusji strategia performatywna wpisana w Lehrstücke prowadzić może do interesujących wyników ${ }^{2}$.

Eksperyment oksfordzki i każdy kolejny, który następował po nim, ożywiała fascynacja słowem poety i przyjemność czerpana z gry słów, modyfikującej ich znaczenie. Reżyser jest mistrzem ceremonii, aranżerem gry. Wprowadzenie gry jako inspirującego modelu dla performance jest oczywiste. Gry są stymulatorem dla słowa i ruchu.

\section{9}

Żartobliwe traktowanie ideologii i fascynacja słownymi obrazami; zabawowa manipulacja dźwięków, znaczeń i kombinacji słów; medialna transpozycja - to główne cechy moich prób dekonstrukcji tekstu przez performance.

Parafrazując słowa autora Fatzera i wprowadzając je w inny kontekst, powiedzieć można:

DER SCHOSS IST FRUCHTBAR NOCH, AUS DEM ES KROCH

czyli (w moim wolnym przekładzie):

PŁODNE JEST JESZCZE ŁONO

Z KTÓREGO WYPEŁZŁO ONO

gdzie „ONO” rozumieć należy jako performance, wbrew polskiej konwencji, która traktuje performance, jakby było rodzaju męskiego.

przełożył Piotr Dobrowolski

2 Zob. E.L. Thomas, A. Wirth, Fatzer: $B B / H M / R W$ Interface, kaseta video, Centre for Performance Studies, University of Sydney, ed. UCLA, Sydney 1994. 
